\title{
ResearchArticle
}

\section{Morphological and pathogenic variability in French bean isolates of Sclerotinia sclerotiorum}

\author{
C. LALFAKAWMA, B.C. DAS AND L.C. BORA
}

\section{SUMMARY}

Studies conducted on morphological and pathogenic variability among 30 isolates of Sclerotinia sclerotiorum (Lib) de Bary, derived from infected French bean (Phaseolus vulgaris) plants showing typical symptoms of white mold, collected from different geographical locations of NE India. All the isolates showed variation in morphological characters based on their mycelial growth, colony character and sclerotial formations when grown on PDA. Out of 30 isolates, 14 isolates showed highly virulent reaction, each 8 isolate revealed moderately and less virulent reaction respectively on French bean under pot condition.

Key Words : Sclerotinia sclerotiorum, Phaseolus vulgaris, White mold, PDA, Virulent

How to cite this article : Lalfakawma, C., Das, B.C. and Bora, L.C. (2016). Morphological and pathogenic variability in French bean isolates of Sclerotinia sclerotiorum. Internat. J. Plant Sci., 11 (2): 340-344, DOI: 10.15740/HAS/IJPS/11.2/340-344.

Article chronicle : Received : 26.04.2016; Revised : 29.05.2016; Accepted : 25.06.2016

\section{MEMBERS OF THE RESEARCH FORUM}

\section{Author to be contacted :}

C. LALFAKAWMA, Department of Plant Pathology, College of Agriculture, Assam Agricultural University, JORHAT (ASSAM) INDIA

Address of the Co-authors:

B.C. DAS, Regional Agricultural Research Station, Titabor, JORHAT (ASSAM) INDIA

L. C. BORA,Department of Plant Pathology, College of Agriculture, Assam Agricultural University, JORHAT (ASSAM) INDIA 